\title{
Special insurance systems for motor vehicle liability
}

\section{Introduction}

Automobile insurance is a compulsory purchase for most drivers in Europe and the United States. Obviously, this obligation raises concerns about affordability and availability. ${ }^{1}$ To mitigate such problems, in most legal systems special facilities have been created, either by policymakers or by insurance companies, to deal with risks that are very difficult to insure or are even considered uninsurable on the commercial market. While individuals with a heavy accident record will often find it impossible to find insurance on the voluntary insurance market, they have a good chance of finding coverage on the involuntary market, also known as the residual or shared market. ${ }^{2}$

Policymakers and insurers have offered different reasons for the creation of such facilities. On the one hand they argue that if these types of facilities are not offered, there is a danger that individuals who cannot find coverage will drive without insurance. The duty to have mandatory insurance for traffic liability is indeed never perfectly enforced. In that case the insolvency risk the uninsureds create will often be shifted to the collectivity of insureds. A second reason is related to the corporate social responsibility of insurers: they consider it their task to provide coverage also for "hard to insure" risks.

\footnotetext{
${ }^{1}$ See e.g. Regan et al. (2009), 24.

${ }^{2}$ The term involuntary follows from the fact that in contrast to a normal competitive market, insurers are not free to select those drivers they wish to insure. The term shared follows from the fact that profit and losses are shared by all insurers selling motor liability insurance.
} 
In this article, we examine the special insurance systems from three perspectives. ${ }^{3}$ First, we analyze the potential benefits of reducing the number of uninsured drivers in society, and look at whether the facilities may be capable of reaching their intended goal, i.e. reducing the number of uninsureds. Second, we examine the influence on drivers' precaution levels and decision to drive. Theory holds that via an appropriate differentiation of premiums, incentives should be provided to potential injurers to adopt preventive measures. To the extent the "hard to insure" individuals would pose a higher risk, one would thus expect higher premiums. These should not only provide incentives for prevention, but also incentives for policyholders to stay only briefly with the special facility in order to return to the voluntary market. However, to the extent that policyholders would not be charged premiums that reflect the risk they pose, problems may arise. First, this could lead to crosssubsidization between the good risks and the bad risks, since it's the collectivity of insureds that pay for the facility. Second, this cross-subsidization could also insufficiently incentivize policyholders. If premiums do not correctly reflect the risk posed by the insured, the (presumably lower) premiums could have the effect of increasing the accident risk. Finally, we examine the social costs of these schemes.

The remainder of this paper is structured as follows. We first provide an overview of special schemes in several European countries (section 2). Section 3 examines the potential advantages of reducing the number of uninsured drivers and investigates the influence of the special schemes on the decision of individuals to drive (un)insured. Section 4 examines the consequences of these schemes for the incentives of drivers. Section 5 discusses the social costs of the special schemes. Section 6 concludes.

\footnotetext{
${ }^{3}$ Previous literature dealing with involuntary motor liability insurance markets have mainly (but not solely) focused on the consequences of regulation of the voluntary market on the size of the involuntary market. See e.g. Grabowski et al. (1989); Regan et al. (2009).
} 


\section{Special insurance schemes in Europe}

In Europe, motor vehicle insurance is mandatory, at least as far as damage to third parties is concerned. This is laid down in various European directives which force the Member States to introduce compulsory insurance for the liability resulting from traffic accidents. ${ }^{4}$ In order to guarantee that victims are also compensated if an accident is caused by an unidentified or uninsured driver, European law equally obliges the Member States to create an institution which assures that victims will not remain without compensation in that particular case. ${ }^{5}$ Every Member State is obliged to set up or authorize a body with the task of providing compensation at least up to the limits of the insurance obligation for damage to property or personal injuries caused by an unidentified vehicle or a vehicle for which the insurance obligation has not been satisfied. ${ }^{6}$ Member States have created Motor Guarantee Funds to fulfill this obligation. For example, in the UK the Motor Insurers Bureau takes on this task. Every civil liability motor insurer is obliged to join this fund and to support it financially in proportion to the number of motor vehicles it insures. ${ }^{7}$ In Belgium (Gemeenschappelijk Motorwaarborgfonds) and the Netherlands (Waarborgfonds Motorverkeer), a similar situation exists. ${ }^{8}$ Note however that European law is silent on how Member States should deal with the situation of high risk drivers who may not be able to afford the premiums. Many legal systems have created particular solutions which we will briefly summarize (Fout! Verwijzingsbron niet gevonden.2.1). We will then focus more in detail on the solutions in Belgium and the Netherlands (Fout! Verwijzingsbron niet gevonden. Z.2). ${ }^{9}$

\subsection{Overview}

\footnotetext{
${ }^{4}$ This follows inter alia from the coordinated Directive 2009/103/EC of 16 September 2009 relating to insurance against civil liability in respect of the use of motor vehicles, and the enforcement of the obligation to insure against such liability, Official Journal, 263/11 of 7 October 2009.

${ }_{6}^{5}$ Article 10, Directive 2009/103 of 16 September 2009.

${ }^{6}$ This follows from chapter 4 of Directive 2009/103.

${ }^{7}$ Note that European law lets the Member States free on how to finance the Funds.

${ }^{8}$ Note that the losses caused by uninsured drivers are ultimately paid by the insureds through increased premiums.

${ }^{9}$ For these two countries, we conducted interviews with the representatives of the special facilities.
} 
As a starting point, a distinction should be made between Member States which impose an obligation on insurers to contract (which in theory should exclude the danger of bad risks being without cover) and Member States where there is no such obligation. A duty to contract exists for example in Germany, Luxemburg, Norway, Sweden and Finland. ${ }^{10}{ }^{11}$ Many other Member States however do not impose an obligation on insurance companies to provide cover. Such an obligation is for example absent in Austria, Switzerland, Spain, France, the United Kingdom, Greece, Ireland and Portugal. ${ }^{12}$

At first sight, it may seem that Member States with an obligation imposed upon insurers to contract will not have problems of insurance availability. However, merely imposing an obligation to contract does not fully guarantee insurance cover to high risk drivers since premiums may be prohibitive. Indeed, for some European legal systems that do have an obligation to contract, it is explicitly mentioned that high risk drivers may still experience problems with finding insurance. For example with respect to Germany, it is pointed out that since there is no particular pool for bad risks, some individuals may have a hard time financing their premiums at general business rates, especially if the degree of risk differentiation would increase. ${ }^{13}$ The same is true for Denmark where it is held that the obligation to provide cover combined with the freedom of insurers to calculate premiums can result in a financing problem for bad risks. ${ }^{14} 15$

In many countries where the legal system does not compel insurers to provide insurance cover, a variety of constructions has been developed to deal with bad risks that are refused by insurers. Some of those solutions have a statutory basis; others are based on self-regulation by insurers. In Austria for example, the institution "Versicherungsnotstand" (underwriting emergency) ensures insurance cover for all risks. A person who has been rejected by at least three underwriters can turn to this

\footnotetext{
${ }^{10}$ See Meyer (2005), 59, 102, 106, 121, 124.

${ }^{11}$ It often concerns a qualified obligation. Often, insurers have to present offers to all customers, unless a limited number of factors prevails (such a previous termination of contract for default in premium payment).

${ }^{12}$ Meyer (2005), 42, 53, 69, 74, 80, 85, 95, 115.

${ }^{13}$ Meyer (2005), 59.

${ }^{14}$ Meyer (2005), 65.

${ }^{15}$ Note however that the number of individuals driving uninsured in Germany and Denmark is very low: around $0.1 \%$. See Retail Insurance Market Study, MARKT/2008/18/H, Final Report by Europe Economics, p. 194, available at http://ec.europa.eu/internal_market/insurance/docs/motor/20100302rim_en.pdf.
} 
association of insurers who will refer him to an insurer who is then obliged to provide cover. The nominated insurer has the right take a surplus of $50 \%$ on the premium according to his commonly used tariff; the insurer may claim a deductible which may amount to no more than the rate of an annual premium. ${ }^{16}{ }^{17}$ In Switzerland, in the 1960's a pool was created for risks which could not find cover on the commercial market. Later, this pool was replaced by an agreement among underwriters regarding the distribution of risks that were not insurable via ordinary policies. Due to deregulation, that agreement terminated on 1 January 1996 as a result of which a fall-back device is now absent. ${ }^{18}$ In Ireland, all motor insurers concluded the "Declined Cases Agreement". Under the agreement, the insurance market will not refuse cover to an individual seeking insurance, if he or she has approached at least three insurers and has not been able to obtain cover. In general, the insurer first approached has to provide the individual with a quote. Where an individual has held a policy within the last three years, the insurance company concerned has to provide the individual with a quotation (once again conditional on refusals having been received from three insurers). An insurer can only refuse cover if providing insurance would be contrary to public interest. The agreement is administered by a Committee made up of representatives of the insurance companies who have signed the agreement. The Committee also includes a representative of the Consumers' Association of Ireland and the Financial Services Ombudsman's Bureau. The Committee can also decide whether a quote is so high or the terms so excessive as to make the quote equivalent to a refusal, in which case it will review the matter. ${ }^{19}$ Still, about $5 \%$ of all car drivers drive uninsured in Ireland. ${ }^{20}$

In addition to the special schemes provided via the market, some countries where there is no obligation to contract have introduced a regulatory solution. For example, in Spain bad motor risks are assumed by the "Consorcio de Compensación de Seguros", a state organization which also

\footnotetext{
${ }^{16}$ See $\S 25$ Kraftfahrzeug-Haftpflichtversicherungsgesetz.

${ }^{17}$ Meyer (2005), 42.

${ }^{18}$ Meyer (2005), 53.

${ }^{19}$ See the website of Insurance Ireland, the representative body of insurers in Ireland, available at http://www.insuranceireland.eu/consumer-information/general-non-life-insurance/motor.

${ }^{20}$ Meyer (2005), 95.
} 
functions as guarantee fund. ${ }^{21}$ It may contract with an individual if two insurance companies have rejected providing cover, unless such risk were to be accepted by another insurance company at the request of the Consorcio de Compensación de Seguros. ${ }^{22}$ In France, in case a person cannot obtain cover on the regular market, the "Bureau Central de Tarification" will assign an insurance company to him and the Bureau will calculate the premium. ${ }^{23}{ }^{24}$ This is comparable to the model of the Belgian Tariferingsbureau which we will discuss below. In Greece, a person who cannot obtain insurance cover on the free market can make a request to a commission of the Ministry for Trade to fix a premium for him which he can ask for in a contract with any insurance company. ${ }^{25}$ In Portugal, when a person has been rejected at least three times, he can turn to the supervisory body (Instituto de Seguros de Portugal) which will refer him to a group of insurance companies which then has to underwrite the risk collectively. ${ }^{26}$

Some countries that do not impose a duty to contract on insurers do not have a special scheme as well. This is for example the case in the United Kingdom. There, some regular insurance companies specialize in providing cover for high risks. ${ }^{27}$ However, it is mentioned that in some situations insurance cover is hard to be obtained or only at very high premiums. Four to six percent of drivers would not be insured in the UK. ${ }^{28}$

We will now focus on two particular examples of the special schemes: one scheme which was created by statute (the Tariferingsbureau Auto in Belgium) and one which is the result of a voluntary collaboration between insurance companies (Rialto in the Netherlands).

\footnotetext{
${ }^{21}$ Meyer (2005), 69. The Consorcio is also active in the area of other risks, see Machetti (2006).

${ }^{22}$ See the website of this institution: http://www.consorseguros.es/web/ad a fe.

${ }^{23}$ Meyer (2005), 74.

${ }^{24}$ See also the website of the Bureau Central de Tarification:

http://www.bureaucentraldetarification.com.fr/BCTA.

${ }^{25}$ Meyer (2005), 85.

${ }^{26}$ Meyer (2005), 115. The website of the Instituto de Seguros de Portugal can be found at www.isp.pt.

${ }^{27}$ See e.g. Acorn Insurance, http://www.acorninsure.co.uk/car-insurance/high-risk-car-insurance/; 4 Young Drivers, http://www.4youngdrivers.co.uk/articles/high-risk-car-insurance.htm.

${ }^{28}$ Meyer (2005), 80.
} 


\subsection{Special schemes in Belgium and the Netherlands}

\subsubsection{Tariferingsbureau Auto (Belgium)}

In Belgium, the "Tariferingsbureau Auto" was created a decade ago as a means of reducing the number of uninsured drivers. ${ }^{29}$ The activities of the Bureau started on November 1st 2003. According to the members of parliament who were the authors of the bill that created the Tariferingsbureau, "the technique of risk differentiation can lead to uninsurability: this can be a technical uninsurability due to the characteristics of the risk itself (dangerousness etc.) but also an economic uninsurability when the insurer does not consider the risk to be profitable". ${ }^{30}$ The authors of the bill were further of the opinion that the problem of uninsured driving should not only be addressed by more efficient law enforcement, but should also be tackled through better prevention. Before the creation of the Tariferingsbureau, there was a Pool for difficult risks, which was an initiative of the insurers only. The Tariferingsbureau consists of 4 members who represent the interests of consumers, and 4 members who represent the interests of insurers. The premiums asked by the Tariferingsbureau are lower than the premiums of the Pool. ${ }^{31}$

Anybody who is obliged to take a motor vehicle liability insurance can make a request to the Tariferingsbureau if at least three regular insurers have refused to offer him insurance or are only willing to provide insurance against a high premium or deductible. ${ }^{32}$ Whether a premium is high is determined as follows. First, the lowest possible premium that the insurer would ask for the vehicle is determined (assuming that the most beneficial conditions regarding age, region, bonus malus degree etc. apply). Then this premium is multiplied with 5 to obtain a treshold value. Whether a deductible is high is determined in the same way, except that the multiplicator is 3 instead of 5 . In reality, almost all of the customers turn to the Tariferingsbureau because they were denied insurance

\footnotetext{
${ }^{29}$ Act of 2 August 2002 concerning mandatory motor vehicle insurance, Moniteur Belge, 30 August 2002.

${ }^{30}$ Parl. Doc., Senaat, 1999-2000, No. 2-247/2.

${ }^{31}$ Report Tariferingsbureau Auto 2003-2008, available via http://www.bt-tb.be/auto/documents/BTB-RAPP2009-FINAL-NL.pdf, p. 44.

${ }^{32}$ Article 9ter paragraph 1 of the Act of 2 August 2002.
} 
and not because they were offered a premium (or deductible) that exceeds the treshold value. ${ }^{33}$ The Bureau is in principle obliged to accept the individual that presents itself. There have only been rare cases where insurance has been refused, for example when someone did not have a valid driver's license or when it was medically shown that someone is not able to drive. ${ }^{34}$

It is statutorily determined that the Tariferingsbureau "determines the premium taking into account the risk of the insured and the apportionment over all insureds". ${ }^{35}$ In practice, this implies that for more severe risks higher premiums can be applied, except if these would become uninsurable. The Tariferingsbureau takes into account the same factors that regular insurance companies use (bonus malus degree, age etc.), but can lower the premium that would be the result of these factors to make payment of the premium possible. The premiums of the Bureau can, at least in theory, exceed the treshold premiums discussed above. However, for passenger cars, a ceiling has been determined for the premium (the exact amount depends on the engine power).

Individuals who come to the Bureau are often quite accident-prone. At the moment of turning to the Tariferingsbureau, they have an incidence of accidents that is at least three times higher than individuals who remain insured in the regular insurance market. The incidence of accidents is substantially higher for younger drivers (+ 5 percent compared to the categories $26-74$ and $75+$ ). ${ }^{36}$ On average, the bonus malus degree of individuals who get a contract from the Tariferingsbureau (and at that moment) is 5 to 6 times higher than the bonus malus degree of individuals who are insured on the regular insurance market (2.4 versus 13.7$).{ }^{37}$ Drivers in the age groups - 26 and $26-74$ had their driver's license revoked much more often than older drivers (+/- 13 percent compared to +/- 3

\footnotetext{
${ }^{33}$ In the period 2003-2008, less than 10 people turned to the Tariferingsbureau after they got proposals with high premiums.

${ }^{34}$ Interview with Mr Leton, chairman of the board of the Bureau on 29 April 2013.

${ }^{35}$ Artikel 9quater, $\S 2$ of the statute.

${ }^{36}$ Report Tariferingsbureau Auto 2003-2008, available via http://www.bt-tb.be/auto/documents/BTB-RAPP2009-FINAL-NL.pdf, p. 26.

${ }^{37}$ Id, p. 44.
} 
percent). ${ }^{38}$ With respect to aggravating circumstances (alcohol and drugs, hit and run, excessive speed, driving uninsured), once again younger drivers are substantially more dangerous than the other categories (the $75+$ category category is least dangerous). ${ }^{39}$ On average, premiums paid by younger drivers are the highest (in between 1400 and 1500 Euro), at the middle for the age group 2674 (between 900 and 1.100 Euro) and lowest for the $75+$ group (750-1.000 Euro). ${ }^{40}$

The administration of the insurance contracts is assigned to a limited number of insurers. The losses of these insurers due to the contracts in which the Tariferingsbureau has determined the premium are reimbursed by the "Gemeenschappelijk Motorwaarborgfonds". Every civil liability motor insurer is obliged to join this Fund and support it financially in proportion to the number of motor vehicles it insures.

\subsubsection{Rialto (the Netherlands)}

Rialto was created in 1966 by a large number of insurers, at that time under the name Terminus. The reason for its creation was that the law had introduced compulsory insurance for motor vehicles. Since not all risks are considered acceptable for the market, Terminus was created to cover risks that could not be insured on the regular market. It seemed socially undesirable that car drivers would otherwise be uninsured. ${ }^{41}$ On its website, Rialto announces "Rialto insures in principle almost everyone. Also when other insurers refuse to provide coverage, because you had a lot of damage in a short time or you did not pay your premium or you were confronted with a criminal conviction" ${ }^{42}$ It is held that commercial insurers too easily decide to exclude particular clients, for example if they have claimed damage twice in a period of 4 years. The director of Rialto claims that excluding those consumers provides a huge practical problem: "When no one is longer willing to provide coverage for

\footnotetext{
${ }^{38}$ Id, p. 38.

${ }^{39}$ Id, p. 28

${ }^{40} \mathrm{Id}, \mathrm{p} .32$.

${ }^{41}$ van Duijse (2013), 10

${ }^{42}$ See http://www.rialto.nl/consument/verzekeringen/index.php?id=1.
} 
a former alcoholic or someone who had several accidents, such a person can no longer get on the road with his car. Car drivers are forced by law to have liability insurance when they drive a car. And in 2003 the right to auto mobility is approximately a fundamental right of the homo economicus" ${ }^{43}$ In some cases Rialto also covers insureds who did not pay their bills with the commercial insurers. They are not necessarily a higher risk (in terms of insurability), but create a higher risk of insolvency. ${ }^{44}$ Most of the insurance provided by Rialto is third party liability insurance, not first party (damage) insurance. The reason is that liability insurance is often necessary for people; damage insurance less so.

Rialto itself does not do business with the consumer. Insureds who wish to opt for the Rialto coverage have to use the services of an insurance intermediary who will contact Rialto and ask for an offer for insurance coverage with an appropriate premium. ${ }_{4}^{45}$ Although, as mentioned before, Rialto insures in principle almost everyone, it will still examine the file and decide in each particular case whether they will indeed provide coverage. Although this is most often the case, there is no automatic acceptance of risks. The decision to grant insurance should still be acceptable from an insurability and commercial perspective. ${ }^{46}$

In principle Rialto charges risk dependent premiums according to the actuarial fair value of the risk. ${ }^{47}$ In sharp contrast with the Belgian Tariferingsbureau, they seldomly depart from this strategy, even for young drivers. ${ }^{48}$ No ceilings apply. The average premium with Rialto equals 1.700 Euro. ${ }^{49}$ Note that this number includes the premiums not only for high risk drivers, but also e.g. for individuals who did not pay their premiums when they were insured on the voluntary market. So the average

\footnotetext{
${ }^{43}$ Interview with Leo Bechtold, the Volkskrant 27 August 2003, http://www.volkskrant.n1/vk/n1/2844/Archief/archief/article/detail/705039/2003/08/27/Rialto-verzekertonverzekerbaren.dhtml.

${ }^{44}$ Ibidem. In those cases particular agreements, e.g. regarding payments in monthly instalments of the premium would be made.

${ }^{45}$ See http://www.depremievergelijker.nl/20/rialto-verzekeringen.

${ }^{46}$ Interview with Mr. Blees and Mr. van Duijse of Rialto on 12 February 2013. See also van Duijse (2013), 11.

${ }^{47}$ Interview with Mr. Blees and Mr. van Duijse of Rialto on 12 February 2013.

${ }^{48}$ Interview with Mr. Blees on 9 May 2014

${ }^{49}$ Information provided through e-mail byMr. van Duijse on 10 May 2014.
} \begin{tabular}{l} 
Met opmaak: Lettertype: Calibri, $11 \mathrm{pt}$ \\
$\begin{array}{l}\text { Met opmaak: Inspringing: Links: } 0 \\
\mathrm{~cm}\end{array}$ \\
\hline
\end{tabular}

Met opmaak: Lettertype: Calibri, $11 \mathrm{pt}$ Met opmaak: Lettertype: Calibri, $11 \mathrm{pt}$ 
premium for high risk drivers could still be considerably larger. According to director Bechtold, premiums with Rialto are up to three times as high as with normal insurers. However, Bechtold claims that car drivers de facto do not have a lot of choice: "it is either Rialto or public transport". ${ }^{50}$ He also claims that the high premiums have the positive side effect of leading to better driving behaviour. To further steer the driving behavior of the insureds, Rialto often applies quite substantial deductibles. ${ }^{51}$ It does not often impose special conditions on its insureds (e.g. not to drive at night or in the weekend etc.). ${ }^{52}$

For Rialto, like for any other commercial insurer, it is important to be financially viable. Rialto asks for premiums which correctly reflect the risk, but does not strive for the same level of profit as commercial insurers. Administrative costs are quite high due to the need to develop expertise regarding special risks. Commercial insurers are not always interested in making these investments. ${ }^{53}$ In principle, Rialto makes profits. In the year 2000, all branches of Rialto together made a profit before taxes of 2, 8 million guilders (1.27 million Euro) and after taxes of 1, 8 million guilders (816.000 Euro), also resulting from profits on investments. ${ }^{54}$ Currently, representatives of Rialto hold that they play break even as far as the motor vehicle insurance part of Rialto is concerned. ${ }^{55}$ Shareholders of Rialto are insurers.

\section{Special schemes and uninsured drivers}

As mentioned in the introduction, one reason that is generally provided to support the introduction of the special schemes is the reduction in the number of uninsured drivers. The logic is simple: when

${ }^{50} \mathrm{http}: / / \mathrm{www} . v 0 l k s k r a n t . n 1 / \mathrm{vk} / \mathrm{nl} / 2844 /$ Archief/archief/article/detail/705039/2003/08/27/Rialto-verzekertonverzekerbaren.dhtml.

${ }^{51}$ Interview with Mr. Blees on 9 May 2014 and information provided through e-mail by Mr. van Duijse on 10 May 2014.

| ${ }_{53}^{52}$ Id.

${ }^{53}$ Interview with Mr. Blees and Mr. van Duijse on 12 February 2013; Interview with Mr. Blees on 9 May 2014

${ }^{54}$ [http://www.bankingreview.nl/?portled=bankingreview\&h=kennisbank/artikel\&id=3752], last accessed on 27 March 2013.

${ }^{55}$ Interview with Mr. Blees and Mr. van Duijse of Rialto on 12 February 2013. 
an individual with a given risk profile can obtain insurance at a premium that is lower than the premium the voluntary market would offer him, he will be more likely to take insurance. We will first look at the potential benefits of decreasing the number of individuals driving without liability insurance, and then at the question whether the special schemes are actually capable of reducing the number of uninsured individuals.

Reducing the number of uninsured individuals allegedly has four benefits: it spreads costs, reduces litigation costs, lowers the accident rate and reduces cross-subsidization. We will now critically examine each of these advantages.

First, uninsured individuals expose both themselves and others ${ }^{56}$ to the possibility that they will have to put up with the totality of their misfortune. Insurance allows an event that is potentially life changing from a financial perspective to have only moderately slight monetary consequences by spreading the costs over all insured drivers. ${ }^{57}$ However, at least as far as the victims are concerned, such misfortune could also be prevented by taking (first party) insurance against the risk of being involved in an accident with an uninsured driver (e.g. the "uninsured motorist clauses" in the US). And with respect to injurers, although they will regret not having taken insurance when they cause an accident, from an ex ante perspective their choice not to be insured may be privately utility maximizing. ${ }^{58}$

Second, the costs of the litigation system may decrease when the number of insureds increases. The reason is that liability insurers are more likely to settle claims quickly and out of court than negligent drivers acting on their own. Consequently, the total costs of responding to a liability claim could be higher for drivers acting on their own. ${ }^{59}$ However, victims will often not bother to even start a claim

\footnotetext{
${ }^{56}$ Since the injurer will often not have enough financial means to pay substantial damage claims.

${ }^{57}$ Baker (2002).

${ }^{58}$ Of course, this will not be the case if the only reason they did not take insurance is that they lack the funds to buy insurance.

${ }^{59}$ Keeton and and Kwerel (1984).
} 
against an uninsured driver, given that nothing or very little can be recuperated. This will reduce the litigation costs and thus also makes the second argument ambiguous.

Third, it is sometimes advanced that insurance may help to prevent harm from occurring by increasing the costs of careless driving. Insureds bear the consequences of their negligent behavior in the form of elevated premiums, uninsured individuals do not. ${ }^{60}$ However, it's uncertain whether, for a given risk profile, uninsured people drive less safe than insured people. On the one hand, uninsured drivers indeed do not bear the consequences of their risky behavior in the form of elevated premiums. But on the other hand, they may behave in a more risk averse manner so as to not expose the fact that they are uninsured. ${ }^{61}$ Moreover, insured individuals exhibit moral hazard, which may to some extent increase the accident rate. ${ }^{62}$ The threat of elevated premiums may not be sufficient to induce safer driving. So from a theoretical point of view, a reduction in the number of uninsured individuals has ambiguous effects on the accident rate. It seems however most likely that the foresight of elevated premiums does not have the same effect as the risk of having to pay all damages and a possible criminal sentence on top. In line with this, empirical research by Cohen and Dehejia (2004) finds that "increasing the incidence of insurance produces an increase in fatalities. The magnitude of this moral hazard effect is potentially large: a two percent increase in fatalities for each percentage point decrease in uninsured motorists." ${ }^{63}$ Others however have found different results. For example, Blows et al (2003) ${ }^{64}$, using data from the Auckland Car Crash Injury Study (19981999), find that uninsured drivers have a significantly greater chance of car crash injury compared to insured drivers after adjustments for age, sex, level of education, and driving exposure. ${ }^{65}$ They find

\footnotetext{
${ }^{60}$ See e.g. Cohen (1997-98), 305.

${ }^{61}$ And if they are not entirely judgment proof, they will bear a part (or all) of the loss they caused.

${ }^{62}$ See e.g. Shavell (1979).

${ }^{63}$ Cohen and Dehejia (2004). With an instrumental variables approach, the authors investigate the incentive effects of automobile insurance, compulsory insurance laws, and no-fault liability laws on driver behavior and traffic fatalities. They analyze a panel of 50 U.S. states and the District of Columbia from 1970-1998, a period in which many states adopted compulsory insurance regulations and/or no-fault laws.

${ }^{64}$ Blows et al. (2003).

${ }^{65}$ Cases were all cars involved in crashes in which at least one occupant was hospitalized or killed anywhere in the Auckland region. Controls were 588 drivers of randomly selected cars on Auckland roads. Participants completed a structured interview.
} 
an odds ratio of 4.77 (95\% confidence interval 2.94-7.75). However, as the authors explicitly admit, the causal mechanism for insurance and car crash injury is not easily determined. The study examined the effects of multiple potential confounders including socioeconomic status and risktaking behaviour, which are known to be associated with both insurance status and car crash injury. Still, residual confounding may still explain the association.

Fourth, in many countries the costs of accidents caused by uninsured motorists are shifted to the insurance industry, and ultimately to the insureds who pay increased premiums. ${ }^{66} 67$ In other words, the uninsured generate a negative externality on the insured. In theory, when this externality is sufficiently large, it may lead individuals who were insured on the voluntary market, many of whom create relatively low risks, to stop driving. Also, some individuals may now decide to drive without insurance, exacerbating the problem. In reality however, the cross-subsidization is often limited. For example, the harm caused by uninsured drivers in Belgium in 2007 was 27 million Euro, adding 4 Euro to the premiums of insured vehicles on the market. ${ }^{68}$ In the UK, the externality is larger: uninsured drivers add at least $£ 30$ per annum to the premia of honest motorists. ${ }^{69}$ In the US, the externality may even be larger. The National Association of Insurance Commissioners states that Americans spent $\$ 186$ billion on automobile insurance premia in 2009 , and approximately $15 \%$ of American drivers lack automobile insurance. With respect to California, a recent empirical study concludes that higher rates of uninsured drivers has a significant effect on the auto insurance premium in that state. The study estimates that a 1-percentage-point increase in the rate of uninsured drivers leads to an increase of $\$ 28$ in automobile insurance premia. Each driver could save

\footnotetext{
${ }^{66}$ See section 2 on Motor Guarantee Funds.

${ }^{67}$ The uninsureds usually do not have sufficient financial means to pay the losses they caused themselves.

${ }^{68}$ See Report Tariferingsbureau Auto 2003-2007, p. 43, available via http://www.bt-tb.be/auto/documents/BTBRAPP-2009-FINAL-NL.pdf .

${ }^{69}$ See Uninsured Driving in the United Kingdom, A report to the Secretary of State for

Transport by Professor David Greenaway, University of Nottingham, July 2004, p. 16, available via http://www.direct.gov.uk/prod consum dg/groups/dg_digitalassets/@dg/@en/@motor/documents/digitalasset/d g_068758.pdf.
} 
almost $\$ 500$ if every motorist in California became insured. This would reduce automobile insurance costs by roughly a third. ${ }^{70}$

So what is the influence of the special schemes on the number of uninsured drivers? Basic economic theory predicts that subsidized systems will reduce the number of uninsured individuals. Consumers who receive premium subsidies bear less than the true expected marginal cost of their decisions regarding insuring and driving decisions and will be more likely to own a car, to drive and to purchase more insurance. ${ }^{71}$ Consequently, a more heavily subsidizing system like the Tariferingsbureau, which does not systematically ask for actuarial fair premiums, should reduce the number of uninsureds more than a system like Rialto, which typically asks actuarial fair premiums. However, whether subsidized systems actually reduce the number of uninsured individuals depends on the reasons why these individuals drive without insurance. In a report on uninsured driving in the UK, the factors that influence the decision to remain uninsured are examined by relying on a mix of qualitative evidence from focus group work and data from regulatory and enforcement agencies. ${ }^{72}$ The study finds that the following factors are relevant: (1) misperception regarding the purpose of third party liability (some individuals think it's not worth taking out insurance because the insurance costs more than the value of the vehicle, and so do not seem to know why third party cover is necessary), (2) misperception regarding the cost of insurance (the costs are often exaggerated), (3) spending choices: a preference for spending on other vehicle enhancements, (4) a low perceived likelihood of being detected, (5) low perceived penalties and (6) the wish to remain outside the law (in order to use a vehicle for some criminal activity). Obviously, the introduction of special schemes will not have any effect on most of these factors. For example, it will not correct misperceptions about the likelihood of detection. Other instruments are necessary here (e.g. information campaigns and/or actually increasing the likelihood of detection). In accordance with the basic economic theory

\footnotetext{
${ }^{70}$ See Teng Sun and Yannelis (2013).

${ }_{72}^{71}$ See Derrig and Tennyson (2011), p. 179.

${ }^{72}$ Uninsured Driving in the United Kingdom, A report to the Secretary of State for

Transport by Professor David Greenaway, University of Nottingham, July 2004, available via http://www.direct.gov.uk/prod consum dg/groups/dg_digitalassets/@dg/@en/@motor/documents/digitalasset/d g_068758.pdf.
} 
described above, the introduction of special schemes may reduce the number of uninsureds through its influence on spending choices. Becoming insured may become more attractive relative to other spending options given the implicit subsidy that the special scheme incorporates for high-risk individuals. However, how large this subsidy needs to be in order to have a significant effect remains an empirical question. Existing research shows that reduced prices do not significantly decrease the number of uninsured drivers. ${ }^{73}$

\section{Special schemes and the incentives for drivers}

In this section, we will examine the consequences of the special facilities on drivers' precaution levels and decision to drive. The precaution levels of individuals who are covered by the special facility of course depend on the incentive schemes that these facilities apply. Given that individuals who make use of the facility are often quite accident-prone (see for example the figures regarding the Belgian Tariferingsbureau), it's extremely important to find ways to give these individuals adequate incentives to drive carefully. ${ }^{74}$ As a starting point, the special facilities take into account the same factors that regular insurance companies use to calculate their premiums (bonus malus degree, age, engine power etc.). However, this does not imply that the special schemes always ask premiums which correctly reflect the risk. ${ }^{75}$ As we have mentioned in section 2, the Belgian Tariferingsbureau for example applies ceilings on the premiums. Compared to systems (like Rialto) which generally stick to actuarial fair premiums, these may substantially lower the premiums that would normally have to be paid. Economic theory predicts that since subsidies reduce the link between insurance risk and insurance prices, drivers face reduced incentives for loss prevention and safety investments due to

\footnotetext{
${ }^{73}$ See e.g. Ma and Schmitt (2000).

${ }^{74}$ In some cases people had an accident every three/four months caused through their wrongful conduct. Those are obviously high risk individuals (interview with Mr Leton, chairman of the board of the Belgian Tariferingsbureau on 29 April 2013).

${ }^{75}$ On the effects of risk classification (or the lack of it), see e.g. Crocker and Snow (2000); Rea (1992).
} 
moral hazard. ${ }^{76}$ Subsidies increase the risky choices of drivers, given that the penalty for risk-taking is lower since regulated prices are less responsive to a driver's actual experience than would be the case under competitive risk-based pricing. So in systems which provide substantial subsidies, we can expect too much driving and a smaller incentive to drive safely. ${ }^{77}$

Systems which provide relatively large premium subsidies may attempt to restore incentives for loss prevention in several ways. The Belgian Tariferingsbureau for example tries to reduce the negative consequences by applying quite substantial deductibles. A deductible is automatically incorporated in the contract whenever the premium would normally have been larger but the ceiling applies, and also when the premium was lowered compared to what would have been the premium if the normal criteria of the Tariferingsbureau were applied. ${ }^{78}$ In theory, this could give incentives to drive carefully. However, the deductibles do not have to be consigned and they do not have a third party effect. That means that the victim can claim full compensation and that the Tariferingsbureau then has to claim back the deductible from the insured. In practice this is often not done. ${ }^{79}$ As a result, the insured does not pay the true cost of the accident risk since the cap put on the premium is too low. ${ }^{80}$ It seems that the Tariferingsbureau mainly tries to reduce the accident frequency by imposing some preventive measures on the insureds: to follow a defensive driving course, to place an instrument in the vehicle that prevents the insured from driving when he's drunk, put restrictions on the type of car that can be used and the moments in time one is allowed to drive etc. ${ }^{81}$ Logically, under these circumstances it is not easy to reduce the accident risk. Even individuals that continue to have 3 to 4 accidents per year will still receive insurance coverage; only their deductible will be increased (and

\footnotetext{
${ }^{76}$ Shavell (1982).

${ }^{77}$ On the consequences of premiums not reflecting expected damages, see e.g. Schwarze et al. (2005).

${ }^{78}$ The Bureau provides the following example: "A 19 year old individual makes a request for a vehicle in the sector tourism and business with engine capacity of $66 \mathrm{~kW}(90 \mathrm{pk})$. Taking into account his bonus malus degree of 22, the premium would normally be 3.172 Euro, with a deductible of 1.250 Euro. The Bureau will however adopt the ceiling of 1.980 Euro and a deductible of 2.000 Euro."

${ }^{79}$ Interview with Mr Leton, chairman of the board of the Belgian Tariferingsbureau on 29 April 2013.

${ }^{80}$ Ibidem.

${ }^{81}$ Ibidem.
} 
there may be some additional preventive measures). ${ }^{82}$ Although the bonus malus degree of the vast majority of individuals improves from the first to the second year with the Bureau ${ }^{83}$, on average the clients of the Tariferingsbureau cause many more accidents than individuals insured on the market (times 2.4). ${ }^{84}$ From an empirical perspective, it is unclear to what extent this reflects on the one hand the inherent differences in driving capabilities between drivers in the commercial market and drivers in the residual market, and on the other hand the weakness of the incentivizing scheme of the Tariferingsbureau.

Logically, we can expect larger losses for systems which provide larger subsidies on premiums. The Tariferingsbureau makes a loss of approximately 3 million euro per year ${ }^{85}$, which is passed on to all insured drivers in Belgium. To be profitable, the Tariferingsbureau claims that the total harm divided by the total premium income (with taxes excluded) needs to be lower than 70 percent (the excess premiums are needed to pay the administrative costs and the commission fees). ${ }^{86}$ However, the actual ratio equals $0.99 .{ }^{87}$ Losses are made especially for beginner drivers of 18 to 20 years old.$^{88}$ Their annual accident frequency is $46.4 \%$, and per accident, the losses amount to 13.553 Euro on average. $^{89}$ This group causes 8.19 times more harm than the premiums they pay. ${ }^{90}$ In the Netherlands, the situation is different. In principle, Rialto charges an actuarial fair premium. Rialto thus acts quite similar as a normal commercial enterprise. Even though it may not be profit seeking, it aims at keeping its activities at a break-even point and claims to be able to do so. Predictably,

\footnotetext{
${ }^{82}$ Ibidem.

${ }^{83}$ Data are available for individuals renewing their policy between October 2008 and January 2009 for the first time in the (largest) sector "tourism and business". There was a decrease for $85 \%$ of the bonus malus rating and an increase for $11 \%$. Such a decrease means that in this system of experience rating (bonus malus) the premium decreases because the insured came into a lower scale.

${ }^{84}$ Report Tariferingsbureau Auto 2003-2008, available via http://www.bt-tb.be/auto/documents/BTB-RAPP2009-FINAL-NL.pdf, p 35 .

${ }^{85}$ Id., p. 43.

${ }^{86}$ Id, p. 33.

${ }^{87}$ Id, p. 34. Not all sectors in which the Tariferingsbureau is active are unremunerative. The largest sector, tourism and business, is profitable (ratio of 0.67). However, this number is only an average for the various age groups. For young drivers, the ratios are extremely high (e.g. 8.19 for beginners of age 18-20).

${ }_{88}$ At least as far as the category tourism and business is concerned.

${ }^{89}$ Report Tariferingsbureau Auto 2003-200, available via http://www.bt-tb.be/auto/documents/BTB-RAPP2009-FINAL-NL.pdf , p. 31.

${ }^{90}$ Id., p. 36.
} 
individuals stay longer on average with the Tariferingsbureau ( 3 to 5 years) ${ }^{91}$ than with Rialto ( 3 (years) $)^{92}$

Special facilities with relatively large subsidies may not only influence the incentives of individuals who are covered by them, but could also alter the incentives of drivers in the commercial market. An individual who is insured on the voluntary market and knows that subsidized schemes exist to which he can turn in case his driving record gets too bad, may have a reduced incentive to drive careful. In other words, the facilities may provide perverse incentives that push individuals at the margin into the involuntary market when slight behavioral adjustments might have allowed them to stay insured in the commercial market. The reduced incentives to drive carefully will increase the accident rate in society. Note that after some time this could overburden the special scheme, so that the scheme will have to ask higher premiums to cut its losses. ${ }^{93}$ Similarly, the existence of the special facilities may influence the decision whether to drive or not. Someone who is insured in the voluntary market and had a couple of accidents in a relatively short period of time, may in the absence of special facilities decide to drive less often in order to reduce the probability of causing another accident and risking to be unable to find insurance coverage. With the facilities, especially the ones that provide substantial subsidies, this incentive to reduce activity levels may be diminished.

The incentives of individuals insured in the commercial market, including low risk individuals, may also be distorted due to cross-subsidization. If the special schemes do not reduce the number of uninsured drivers but only attract high-risk drivers who would otherwise have decided not to drive anymore, cross-subsidization may increase (if the special facility makes losses, which is for example the case in Belgium). Due to the increased premiums ${ }^{94}$, some low-risk individuals may decide not to drive anymore or drive too cautiously. ${ }^{95}$ Of course, under other conditions, the special schemes may

\footnotetext{
${ }^{91}$ Id., p. 42.

${ }^{92}$ Interview with Mr. Blees and Mr. van Duijse of Rialto on 12 February 2013.

${ }^{93}$ Some of the individuals who are proposed a high premium may decide to drive uninsured and, at least in theory, the number of uninsured drivers could in the end be larger with the scheme than without it.

${ }^{94}$ And due too large (Bonus Malus System) surcharges in case of an accident.

${ }^{95} \mathrm{On}$ the consequences of premiums not reflecting expected damages, see e.g. Schwarze et al. (2005).
} 
reduce cross-subsidization. This will for example be the case if the schemes do reduce the number of uninsured drivers, and the premiums asked by the scheme are actuarially fair (like in the Netherlands).

\section{The influence of special schemes on social costs}

Investigating the influence of the special schemes on total social costs is quite a challenging task. First of all, one needs to examine the influence on risk costs, administrative costs and incentive costs to get a full picture. Second, the behavior of different types of actors is influenced by the introduction of such schemes (not only individuals covered by the scheme but also individuals not (yet) covered by it). Third, existing relevant empirical research is often ambiguous, making precise predictions impossible.

Introducing a special scheme can reduce risk costs, especially if these schemes reduce the number of uninsured drivers. This is more likely for schemes with relatively large subsidies (e.g. the Belgian Tariferingsbureau) than for systems which provide no or small subsidies (e.g. Rialto). Individuals who drove uninsured before and who now decide to contract with the special facility bear substantially less risk. The possibility of losing all or a considerable part of their financial means ${ }^{96}$ in case they cause an accident is considerably reduced. ${ }^{97}$ Also, potential victims face a smaller risk of being injured by an uninsured individual, which reduces the chance that they will have to bear their own losses. ${ }^{98}$ Finally, individuals who are still insured on the commercial market but have caused several accidents, now face a smaller risk of not finding insurance anymore in case they still cause additional accidents.

\footnotetext{
${ }^{96}$ If they are not judgment proof at least.

${ }^{97}$ Also, they do not face the risk of criminal sanctions for driving without liability insurance.

${ }^{98} \mathrm{We}$ stress however that potential victims may be able to take first party insurance against the risk of being injured by an uninsured driver. And in many countries funds exist to compensate victims of uninsured injurers (e.g. in all the EU countries).
} 
For one group however, the scheme increases risk costs. Individuals who decided not to drive in the absence of the special facility, but now choose to contract with the facility, bear the risk of having to pay a fraction of the loss in case of an accident. This risk is however limited.

Administrative costs may either increase or decrease due to the introduction of the special facility. They may increase because of the transaction costs that follow from the contracts that the special facility enters into with individuals who would otherwise have decided not to drive anymore or who were driving uninsured. This increase in costs is more likely for systems with relatively large subsidies, because these schemes may be able to change the choice between driving and not driving, and between driving with or without insurance. Administrative costs may decrease if the schemes reduce the number of uninsured drivers, because there will be less criminal procedures (for driving without insurance). Also, it may be efficient to decrease the investments in detecting uninsured drivers, which also saves costs. These criminal cost savings are more likely to be larger for schemes with relatively large subsidies, because these schemes may be able to change the choice between driving with or without insurance. Finally, as we have argued in section 3 , if the special schemes have an influence on the number of uninsured drivers, civil litigation costs may either increase or decrease.

The influence of the special facilities on the decision whether to drive or not (and how much) and how careful people drive have important implications for the total costs of accidents in society. Through its influence on the decision whether to drive, the special facilities may increase the accident costs: (1) because some high-risk individuals who would have decided not to drive anymore will now drive due to the subsidized scheme, (2) because some high-risk individuals who were driving without insurance may now become insured and may decide to drive more often (e.g. they were driving less before in order not to expose their uninsured status), and (3) because some individuals who are still insured on the commercial market may not feel the need to drive less in order to reduce the probability of causing an(other) accident which could lead insurers to refuse them coverage in 
the future (because they know they can use the subsidized scheme). ${ }^{99}$ At the same time, if crosssubsidization is substantial, the special schemes can cause low risk individuals to drive less. Taken together, the special schemes may alter the composition of drivers in a negative way (more bad risks, less good risks), which creates welfare losses. ${ }^{100}$ The total societal accident costs may also increase because the schemes do not always provide adequate incentives for individuals covered by it to drive careful (see e.g. the situation in Belgium), and because they may distort the incentives of drivers who are still insured on the commercial market (see above). As we have seen in section 3 , if the special schemes reduce the number of uninsured drivers, the formerly uninsured drivers may either drive more or less careful. The theoretical and empirical research in this context is ambiguous.

\section{Conclusion}

Several European countries have introduced special schemes which provide motor liability insurance to individuals who are denied coverage on the commercial market. One of the main goals of these systems is to reduce the number of uninsured drivers. However, current theoretical insights and empirical findings are ambiguous whether these systems actually reduce the number of uninsured drivers and if they do, whether the accident frequency would decrease. To gain more insight into the welfare effects of the special schemes, further empirical research needs to be undertaken on at least three levels : (1) research which analyzes how large subsidies need to be in order to have an effect on the decisions of uninsured drivers, (2) research which sheds more light on the accident frequency of uninsured drivers compared to insured drivers and (3) more in-depth analyses of the precise incentive schemes the various special facilities in Europe use.

\footnotetext{
${ }^{99}$ Of course, the social costs of the accidents due to the increased activity levels are partially offset by the increased utility of the high risk drivers (who would otherwise be forced e.g. to take the bus etc.).

${ }^{100}$ See Rea (1992).
} 


\section{List of references}

Baker, T., "Risk, Insurance and the Social Construction of Responsibility", in Baker, T. and Simon, J.

(eds), Embracing Risk: the Changing Culture of Insurance and Responbility, 2002, p.33-49.

Blows, S. et al, 'Car Insurance and the Risk of Car Crash Injury', Accident Analysis and Prevention, Vol.35, (2003), pp.987-990.

Brown, J.P., "Toward an Economic Theory of Liability", Journal of Legal Studies (JLS), 1973, p.323-349.

Calabresi G., The Costs of Accidents. A Legal and Economic Analysis, New Haven, Yale University Press, 1970.

Coase, R.H., "The Problem of Social Cost", Journal of Law and Economics (JLE), 1960, p.1-44.

Cohen, A. and Dehejia, R., "The Effect of Automobile Insurance and Accident Liability Laws on Traffic Fatalities", Journal of Law and Economics, 2004, p.357-393.

Cohen, G.M., "Legal Malpractice Insurance and Loss Prevention: A Comprehensive Analysis of Economic Institutions", 4 Connecticut Insurance Law Journal, 1997-1998, p.305.

Crocker, K., Snow, A. (2000), The theory of risk classification, in: Dionne, G. (ed.), Handbook of Insurance, Kluwer Academic Publisher, Dordrecht, 245-276.

Derrig, R. and Tennyson, S., "The Impact of Rate Regulation Claims: Evidence From Massachussetts Automobile Insurance", Risk Management and Insurance Review, 2011, Vol. 14, No. 2, 173-199 Diamond, P., "Single Activity Accidents", 3 Journal of Legal Studies, 1974, p. 107-164.

Faure, M., "Economic Analysis of Fault", in Widmer, P. (ed.), Unification of Tort Law: Fault, Alphenaan-den-Rijn, Kluwer Law International, 2005, p.311-330.

Faure, M., "Is Risk Differentiation on European Insurance Markets in Danger?", Maastricht 14 Journal of European and Comparative Law, 2007, p.83-100. 
Faure, M. and Hartlief, T., Insurance and Expanding Systemic Risks, Paris, OECD, 2003.

Grabowski, H., W.K. Viscusi and W.S. Evans, 1989. "Price and Availability Tradeoffs of Automobile Insurance Regulation." Journal of Risk and Insurance, 56: 275-299.

Houben, I.S.J., "Contractdwang en Verzekering”, in Hartlief, T. and Mendel, M.N. (eds), Verzekering en Maatschappij, Kluwer, Deventer, 2002, p.298-298.

Keeton, W.R. and Kwerel, E., "Externalities in Automobile Insurance and the Uninsured Driver Problem", 27 Journal of Law \& Economics, 1984, p.149-179.

Landes, W. and Posner, R., "The Positive Economic Theory of Tort Law”, 15 Georgia Law Review, 1981, p.851-924.

Ma, Y.L. and Schmit, J.T. (2000) Factors Affecting the Relative Incidence of Uninsured Motorists Claims, Journal of Risk and Insurance Vol. 67, No. 2, 281-294.

Machetti, Ignacio (2006), "The Spanish Experience in the Management of Extraordinary Risks, Including Terrorism", in OECD, Catastrophic Risks and Insurance, OECD Publishing. http://dx.doi.org/10.1787/9789264009950-19-en.

Meyer, U. (2005), Final Report for the Project Car Insurance Tariffs Part III, Motor Liability Insurance in Europe, Comparative Study of the Economic-Statistical Situation, available via http://www.unibamberg.de/fileadmin/uni/fakultaeten/sowi professuren/vwl sozialpolitik/Meyer Seiten/literatur/ Meyer-2005-Motor-Liability-Insurance-Comparative-Study.pdf.

Polinsky, A.M., Introduction to Law and Economics, Boston and Toronto, Little, Brown \& Co, 1983.

Priest, G., "The Government, the Market and the Problem of Catastrophic Loss", 12 Journal of Risk and Uncertainty, 1996, p.219-237.

Rea, S.A. (1992), Insurance Classifications and Social Welfare, in: Dionne, G. (ed.), Contributions to Insurance Economics, Boston-Kluwer Academic Publishers, 377-396. 
Regan, L., Tennyson, S. and Weiss, M., The Relationship Between Auto Insurance Rate Regulation and Insured Loss Costs: An Empirical Analysis, Journal of Insurance Regulation, 2009.

Schäfer, H.B. and Müller-Langer, F., "Strict liability versus negligence", in Faure, M. (ed.) Tort Law and Economics, Cheltenham, Edward Elgar, 2009, p.3-45.

Schwartz, G., "Mixed Theories of Tort Law: Affirming both Deterrence and Corrective Justice”, 75 Texas Law Review, 1997, p.1801-1834.

Schwarze, Reimund \& Wein, Thomas, 2005. "Is the market classification of risk always efficient? Evidence from German third party motor insurance," German Risk and Insurance Review (GRIR), University of Cologne, Department of Risk Management and Insurance, vol. 1(4), pages 173-202.

Shavell, S., "On Moral Hazard and Insurance", Quarterly Journal of Economics, 1979, p.541-562.

Shavell, S., "Strict Liability versus Negligance", Journal of Legal Studies, 1980, p.1-25.

Shavell, S., “On Liability and Insurance”, Bell Journal of Economics, 1982, p.120-132.

Shavell, S., Economic Analysis of Accident Law, Cambridge, Harvard University Press, 1987.

Teng Sun, Stephen and Constantine Yannelis, The Real Effects of the Uninsured on Premia, Working

Paper (September 2013), available via

http://mpra.ub.unimuenchen.de/50087/1/MPRA paper 50087.pdf.

van Duijse, L., “Onverzekerbaar? Daar is Rialto nog niet zo zeker van”, De Beursbengel, No. 823, April 2013, p.10. 